\title{
ANAEROBIC METABOLISM IN UPOGEBIA PUGETTENSIS AND CALLIANASSA CALIFORNIENSIS (CRUSTACEA, THALASSINIDEA)*
}

\author{
ERNST ZEBE ${ }^{\dagger}$ \\ Friday Harbor Laboratories, University of Washington, Friday Harbor, WA 98250, U.S.A.
}

(Received 15 December 1981)

\begin{abstract}
Glycogen is the only significant substrate in the anaerobic metabolism of Upogebia pugettensis and Callianassa californiensis. Small quantities of aspartate are utilized in addition.

2. L-lactate is accumulated as the main end-product and L-alanine and succinate are minor endproducts.

3. Striking differences between both species were found in the amounts of glycogen stored, in the rate of lactate production and in the resistance of anoxia.

4. Accumulation of lactate also occurs in the natural habitat, but the levels reached are rather low.

5. The results suggest that in crustaceans lactate formation is the characteristic mode of anaerobic metabolism as opposed to other invertebrates.
\end{abstract}

\section{INTRODUCTION}

Numerous invertebrates living in certain fresh-water or marine habitats have to cope, more or less frequently, with hypoxic or even anoxic conditions. They survive because they are able to sustain their energy production, although at reduced rates, by employing anaerobic processes. The main features of their anaerobic metabolism were elucidated during recent years. Succinate was shown to arise as characteristic metabolite of glycogen degradation in several molluscs and annelids as well as in some species belonging to other phyla, whereas propionate and acetate are end-products which accumulate in the animals and which, to a large extent, are excreted into the surrounding water (de Zwaan, 1977; Zebe, 1976; Schöttler, 1980). Very few investigations have been carried out using crustaceans. The results published so far seem to indicate that this mode of anaerobic metabolism does not play a significant role in that group, if it is present at all.

Crustaceans, as a rule, are very mobile and show little tolerance of anoxia or hypoxia (von Brand, 1946). However, there seem to be exceptions: the decapods Callianassa californiensis and Upogebia pugettensis which live in burrows in intertidal mud flats were reported to survive three to five days at complete anoxia at $10^{\circ} \mathrm{C}$ (Thompson and Pritchard, 1969). After incubation in the absence of oxygen, lactate in the haemolymph was shown to be elevated to about $6 \mathrm{mM}$ in the former species and to more than $40 \mathrm{mM}$ in the latter, but no corresponding decrease in the glycogen level was observed (Pritchard and Eddy, 1979). These results were interpreted as to suggest that, at least in Callianassa, metabolic processes other than normal glycolysis might provide for the energy in coping with the lack of oxygen.

*The investigation was supported by the Deutsche Forschungsgemeinschaft (Ze 40/15-1).

† Present address: Zoologisches Institut der Universität Münster Lehrstuhl für Tierphysiologie, Hindenburgplatz 55, D-4400 Münster, Federal Republic of Germany.
It seemed worthwhile, especially under comparative aspects, to investigate in detail the anaerobic metabolism of both species. In the present paper the results of experiments will be reported which were carried out with the aim to provide answers to the following questions:

(1) What are the end-products, major and minor, of anaerobic glycogen breakdown that accumulate in Upogebia pugettensis and in Callianassa californiensis? Are other substrates utilized besides glycogen?

(2) What are the rates of substrate utilization and/or end-product accumulation? How do they compare with data obtained from other invertebrate animals?

(3) To what extent do Callianassa and Upogebia rely on anaerobic energy production in their natural habitat?

\section{MATERIALS AND METHODS}

Animals

Upogebia pugettensis and Callianassa californiensis were dug out in False Bay, San Juan Island, Washington. After removal from its burrow each individual was put into a separate plastic bag in $200-300 \mathrm{ml}$ of water to prevent them fighting and hurting each other. In the laboratory the shrimps were individually placed in artificial burrows made from pieces of plastic tube $(40 \times 200 \mathrm{~mm})$, the open ends closed with nylon gauze. These burrows were kept in large tanks connected with the sea water circulation system $\left(10^{\circ} \mathrm{C}\right)$. Twenty-four hours after they had been caught the animals were used in the experiments.

Adults of both sexes in the intermoult stage were selected. Females carrying eggs were left in their habitat. The ratio fresh weight/dry weight was $5.10 \pm 0.29(n=5)$ in Callianassa and $4.08 \pm 0.03(n=6)$ in Upogebia.

\section{Experimental procedure}

In one series of experiments the shrimps were placed individually in large test tubes $(30 \times 200 \mathrm{~mm})$ containing $50 \mathrm{ml}$ anoxic water (previously gassed with nitrogen for 45-60 min). Gassing was continued for $30 \mathrm{~min}$ with the animals in the tubes which subsequently after closing were incubated in a darkened water-bath at $12^{\circ} \mathrm{C}$. The shrimps 
in their tubes stayed mostly close to the surface of the water which probably is their normal resting position (Hill, 1981). Upogebia was seen ventilating vigorously with the pleopods most of the time, whereas such activity was less frequently observed in Callianassa and, in addition, appeared to be also less intense.

In another series of experiments several individuals were placed together in large Erlenmeyer flasks containing $1000 \mathrm{ml}$ anoxic water. Gassing with nitrogen was continued for $30 \mathrm{~min}$ with the animals in the flasks, except when incubation periods of $60 \mathrm{~min}$ were chosen and gassing was reduced to $15 \mathrm{~min}$. Initially the shrimps excitedly moved around in the flasks and only gradually quietened down. At the end of the incubation period the animais were quickly removed from the tubes or flasks, blotted dry and dropped into liquid nitrogen. In the first series of experiments the incubation water was also frozen.

For analysing the shrimps under the conditions of their natural habitat they were dropped into liquid nitrogen immediately after they had been removed from their burrows. Two groups of animals were prepared in each experiment: the first while the habitat was still flooded and the second after maximal (about $7.5 \mathrm{hr}$ emersion of the place)

\section{Preparation of extracts}

The frozen animals were ground to a fine powder in a mortar previously cooled by liquid nitrogen and the frozen powder was brought into pre-weighted vessels containing either $3 \mathrm{~N}$ perchloric acid or $30 \%$ potassium hydroxide. After weighing, PCA was added to a ratio tissue/fluid of $1: 3$, the mixture homogenized, centrifuged and the sediment extracted once more. The pooled extracts were adjusted to about $\mathrm{pH} 6$ by adding $5 \mathrm{M} \mathrm{K}_{2} \mathrm{CO}_{3}$ and the precipitated $\mathrm{KClO}_{4}$ was removed by centrifugation. Extraction with $\mathrm{KOH}$ (tissue/KOH 1:5) was carried out for $30 \mathrm{~min}$ in a water bath at $100^{\circ} \mathrm{C}$, the residue spun down and the extraction repeated.

\section{Measurement of metabolites}

In the PCA extracts glucose, L-lactate, malate, succinate, alanine, aspartate, glutamate and ethanol were measured using standard procedures of the optical test (Bergmeyer, 1974). Glycogen was precipitated in the $\mathrm{KOH}$ extracts by adding of threefold volume of ethanol, after centrifugation redissolved in acetate buffer, $\mathrm{pH} 4.8$, hydrolysed with amyloglucosidase and estimated enzymatically as glucose.

\section{RESULTS}

Concentrations of metabolites under aerobic and anaerobic conditions.

As Table 1 shows, the concentrations of glucose in both Callianassa and Upogebia are low under aerobic conditions. Anoxia causes a substantial increase, about 2.5-fold in Callianassa and 4.5-fold in Upogebia, which can be followed by a decrease during prolonged lack of oxygen in Upogebia. The level of lactate is as low as $0.2-0.3 \mu \mathrm{mol} / \mathrm{g} \mathrm{f.w}$. in animals kept in well oxygenated water, but it dramatically increases during anoxia. Lactate accumulation is strikingly different, however, in both species, Upogebia showing twofold or threefold higher concentrations than $\mathrm{Cal}$ lianassa. In the incubation water of the former species some lactate appeared regularly, although its quantity did not exceed $7-8 \%$ of that accumulated in the body. In contrast to this, only traces of lactate were detected in the incubation water of Callianassa. No other metabolite was found to have been excreted.

In both Thalassinidea alanine normally is present in rather high concentrations which increase somewhat during anaerobiosis. Succinate has a low level under aerobic conditions and shows a larger relative rise during anoxia, but the absolute quantities involved are rather small. The concentration of aspartate decreases in the absence of oxygen and the extent of the change is similar to that of succinate. No significant change was found in the concentration of glutamate. There were always only traces of malate. Production of ethanol was never detected.

\section{Rate of glycolysis}

The accumulation of lactate after various periods of anoxic incubation was measured in both species. The results of one such series of experiments are shown in Fig. 1. In Upogebia, lactate formation was very rapid during an initial phase of about six hours. Later, it slowed down considerably. In Callianassa, the concentration of lactate increased almost linearly during $24 \mathrm{hr}$. The rate, however, was less than $30 \%$ of that found in Upogebia. After $24 \mathrm{hr}$ of anoxia lactate had

Table 1. Concentrations of metabolites ( $\mu \mathrm{mol} / \mathrm{g} \mathrm{f.w.)}$

\begin{tabular}{|c|c|c|c|c|c|c|c|c|}
\hline \multirow{2}{*}{$\begin{array}{c}\text { Hours of } \\
\text { anoxia }\end{array}$} & \multirow[b]{2}{*}{ Glucose } & \multicolumn{2}{|c|}{ Lactate } & \multirow[b]{2}{*}{ Alanine } & \multirow[b]{2}{*}{ Aspartate } & \multirow[b]{2}{*}{ Glutamate } & \multirow[b]{2}{*}{ Succinate } & \multirow[b]{2}{*}{ Malate } \\
\hline & & $\mathrm{b}$ & $\mathrm{w}$ & & & & & \\
\hline \multicolumn{9}{|l|}{ Callianassa } \\
\hline 0 & $0.25 \pm 0.15$ & $0.33 \pm 0.08$ & & $4.5 \pm 0.26$ & $0.87 \pm 0.19$ & $1.55 \pm 0.33$ & $0.21 \pm 0.03$ & $<0.2$ \\
\hline$(n=6)$ & $0.64 \pm 0.17$ & $11.3 \pm 0.6$ & $<0.05$ & $4.15 \pm 0.45$ & $0.38 \pm 0.16$ & $1.61 \pm 0.31$ & $0.52 \pm 0.14$ & $<0.1$ \\
\hline $\begin{array}{c}24 \\
(n=8)\end{array}$ & $0.61 \pm 0.28$ & $16.8 \pm 3.2$ & $0.15 \pm 0.06$ & $6.9 \pm 1.4$ & $0.24 \pm 0.03$ & $1.01 \pm 0.31$ & $0.82 \pm 0.17$ & $<0.1$ \\
\hline \multicolumn{9}{|l|}{ Upogebia } \\
\hline $\begin{array}{c}0 \\
(n=8)\end{array}$ & $0.29 \pm 0.17$ & $0.18 \pm 0.07$ & & $2.33 \pm 0.62$ & $0.49 \pm 0.24$ & $1.50 \pm 0.42$ & $0.13 \pm 0.04$ & $<0.2$ \\
\hline $\begin{array}{c}12 \\
(n=6)\end{array}$ & $1.39 \pm 0.22$ & $22.1 \pm 5.6$ & $0.6 \pm 0.4$ & $4.63 \pm 0.62$ & $0.18 \pm 0.06$ & $1.1 \pm 0.4$ & $0.56 \pm 0.12$ & $<0.2$ \\
\hline $\begin{array}{c}24 \\
(n=8)\end{array}$ & $0.40 \pm 0.09$ & $36.4 \pm 9.3$ & $2.0 \pm 0.8$ & $3.90 \pm 0.80$ & $<0.1$ & $1.6 \pm 0.4$ & $0.58 \pm 0.15$ & $<0.2$ \\
\hline
\end{tabular}




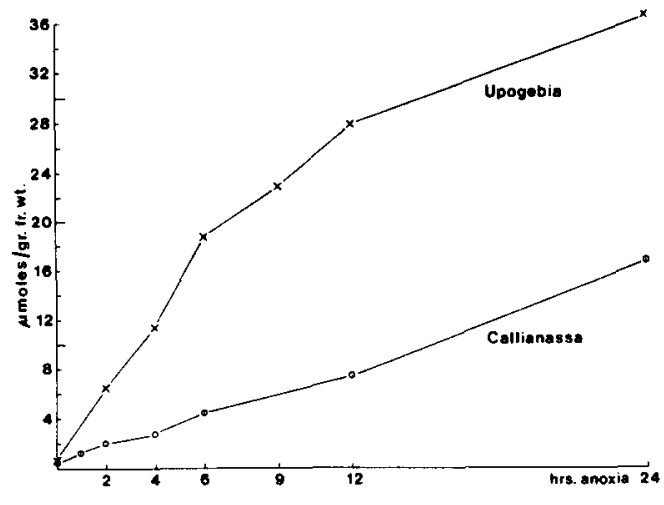

Fig. 1. Concentration of lactate in Upogebia pugettensis and Callianassa californiensis after various periods of anoxia.

risen to $40 \mu \mathrm{mol} / \mathrm{g}$ f.w. and sometimes even to $50 \mu \mathrm{mol}$, whereas in Callianassa the concentration of this metabolite rarely exceeded $20 \mu \mathrm{mol} / \mathrm{g}$ f.w.

Balance: mobilisation of glycogen in relation to the accumulation of lactate

The glycogen content of Callianassa and Upogebia was measured before and after $24 \mathrm{hr}$ of anoxic incubation and it was compared to the production of lactate, in order to check how well the changes in the concentrations of both compounds correspond. A significant difference between glycogen breakdown and lactate accumulation would indicate that substantial quantities of metabolites had been formed which had remained undetected because of a too limited range of analyses performed.

Upogebia was regularly found to have much larger stores of glycogen than Callianassa. As is evident from Table 2, the quantity of glycogen that disappeared during $24 \mathrm{hr}$ of anoxia in the experiment shown is almost equal to the accumulation of lactate measured.

Lactate concentrations in animals living in their natural habitat

It seemed especially important to investigate the Thalassinid shrimps when living in their natural habitat under conditions of changing oxygen supply. In both species, lactate concentrations were measured shortly before the emersion and after maximal duration of the low tide. Under the conditions of normal ventilation of the water in their burrows when the

Table 2. Changes of the glycogen content during experimental anoxia $(\mu \mathrm{mol} / \mathrm{g} \mathrm{f.w}$.)

\begin{tabular}{lcc}
\hline $\begin{array}{c}\text { Hours of } \\
\text { anoxia }\end{array}$ & Upogebia & Callianassa \\
\hline $\begin{array}{lll}\text { Glycogen } \\
0\end{array}$ & 43.6 & \\
24 & 24.6 & 16.4 \\
$\quad$ difference & 19.0 & 8.3 \\
Lactate & & \\
24 & 38.0 & 16.0 \\
\hline
\end{tabular}

Mean values from 4 (Upogebia) and 3 (Callianassa) individuals, respectively.
Table 3. Tide related changes of the lactate concentration ( $\mu \mathrm{mol} / \mathrm{g} \mathrm{f.w.})$

\begin{tabular}{ccc}
\hline $\begin{array}{c}\text { Emersion } \\
(\mathrm{hr})\end{array}$ & Upogebia $(n=10)$ & Callianassa $(n=6)$ \\
\hline 0 & $0.60 \pm 0.25$ & $0.34 \pm 0.05$ \\
7.5 & $2.62 \pm 1.37$ & $1.81 \pm 0.25$ \\
\hline
\end{tabular}

habitat was flooded, i.e. when the supply of oxygen was normal, lactate concentrations were low (although not as low as in animals which had been kept for $24 \mathrm{hr}$ in well-aerated water in the laboratory).

As shown in Table 3, there is a distinct elevation in the level of lactate after $7.5 \mathrm{hr}$ emersion of the habitat, when efficient ventilation of the burrows must become difficult. The lactate concentrations of individual shrimps, however, show rather wide fluctuations which indicate that some individuals must have a better supply of oxygen than others.

Generally, the quantities of lactate found in animals after $7.5 \mathrm{hr}$ emersion are much lower than in those which had been kept for $6 \mathrm{hr}$ in complete anoxia (Fig. 1). In Callianassa the rise found in the respective experiments was twofold higher and in Upogebia as much as sixfold higher than under the conditions of the natural habitat. It is important, however, to point out that on the days when the shrimps were investigated in the mud flats, weather was anything but extreme. (On 6 June, 1981, the temperature of the water in the burrows rose from 11.5 to $14.5^{\circ} \mathrm{C}$ during the emersion period and on 6 July, 1981, from 15 to $19^{\circ} \mathrm{C}$, respectively.) Therefore, lactate may rise to considerably higher concentrations under more severe conditions of the natural environment.

\section{DISCUSSION}

As has been shown above, glycogen is the most important and, in fact, the only significant substrate of anaerobic metabolism in Upogebia and Callianassa and lactate is the principal end-product. In addition, utilization of small quantities of aspartate was found which corresponded to an increase of succinate suggesting that both compounds are interdependent as was shown previously in some molluscs and annelids (Collicutt and Hochachka, 1977; Felbeck, 1980; Schöttler, 1980). Alanine was another minor end-product, its carbon chain probably being also derived from glycogen. Since alanine accumulation is only $5-10 \%$ of lactate production, the balance between glycogen mobilized and end-products measured is still satisfactory. However, the origin of the $\mathrm{NH}_{2}$-groups of alanine is obscure, since only $30 \%$ can be accounted for by the utilization of aspartate.

There is no indication that in these Thalassinidea formation of succinate and volatile fatty acids could be responsible for anaerobic energy production as Pritchard and Eddy (1979) concluded from the very low concentrations of lactate present in the haemolymph of Callianassa after exposure to anoxia. Analysing the whole animals we were able to demonstrate that anoxia caused similar and rather slight increases in the level of succinate in both species which amounted to less than a fifth of what can be found 
under similar conditions in a true facultative anaerobic animal like Arenicola marina (Surholt, 1977; Schöttler, 1980). Therefore, the conclusion drawn by Pritchard and Eddy (1979) seems to be wrong. We feel certain that anaerobic metabolism of both Upogebia and Callianassa is characterized by classical glycolysis leading to the accumulation of lactate only, which, under extreme (experimental) conditions, can rise to very high concentrations. There are striking differences, however, between Upogebia and Callianassa in the rate of lactate accumulation which, during an initial phase of anaerobiosis, is at least threefold higher in the former than in the latter. Even after maximum periods of anoxia, lactate levels in Callianassa hardly exceed $20 \mu \mathrm{mol} / \mathrm{g} \mathrm{f.w}$. whereas in Upogebia the average accumulation during $24 \mathrm{hr}$ of anoxia was 36- $40 \mu \mathrm{mol}$ (maximum values $50-60 \mu \mathrm{mol}$ ). The different rates of glycolysis in both species probably indicate differences in the general metabolic rates which may be related to their specific modes of life (MacGinitie, 1930, 1934). This conclusion seems to be supported by the fact that oxygen consumption also is different in both species, $18-28 \mathrm{ml} / \mathrm{g} \mathrm{f.w.} \times \mathrm{hr}$ in $\mathrm{Cal}$ lianassa and $60-70 \mathrm{ml}$ in Upogebia, respectively, according to Thompson and Pritchard (1969). Thus the ratio of oxygen uptake in both species is very similar to that of lactate production.

In addition to the lower metabolic rate in Callianassa the glycogen store of this species is also only about half of that found in Upogebia. Degradation of glycogen in both Thalassinidea is rather slow in comparison to other invertebrate animals. For example, in the annelid worms Arenicola and Tubifex, $24-30 \mu \mathrm{mol} / \mathrm{g}$ f.w. glycogen were utilized during $24 \mathrm{hr}$ of experimental anaerobiosis at $14^{\circ} \mathrm{C}$ (Schöttler and Schroff, 1976, Fahrenholz, personal communication) and in the larvae of the midge Chironomus $80-85 \mu \mathrm{mol}$ (Wilps and Zebe, 1976).

The difference in the general rate of metabolism in both Thalassinidea probably is also the main reason for their different resistance of anoxia. Whereas Upogebia survived only $26-30 \mathrm{hr}$ in the absence of oxygen, the maximum survival period observed in Callianassa was twice as long. The metabolism rate was not affected whether the shrimps were individually kept in small tubes containing only $50 \mathrm{ml}$ water or whether several individuals together were incubated in much larger volumes of water. In contrast, the survival times of the same species reported by Thompson and Pritchard (1969) are substantially longer: at least three days in Upogebia and up to 5.5 days in Callianassa, respectively. We are unable to explain the reason for this striking discrepancy.

Accumulation of large quantities of lactate during hypoxia and anoxia has also been observed in other crustaceans: Uca pugnax (Teal and Carey, 1968), the isopod Cirrolana borealis (de Zwaan and Skjoldal, 1979) and several cirripeds (Barnes et al., 1963). The rates of formation and accumulation in most of these species were even higher than those measured in the Thalassinidea and the concentrations reached after $18-24 \mathrm{hr}$ of anoxia were sometimes as high as 60-80 $\mu \mathrm{mol} / \mathrm{g}$ f.w. In Cirrolana and in certain cirripeds, in contrast to $U c a$ and the Thalassinidea, large proportions of the lactate formed were found to have been excreted into the water. It is difficult, however, to tell whether this is a normal physiological process or is due to the extreme and unphysiological extent of end-product accumulation.

Formation and accumulation of metabolites other than lactate so far have been reported only from $\mathrm{Cir}$ rolana de Zwaan and Skjoldal, 1979). In this isopod some succinate, propionate and acetate was detected in individuals which had been fed before they were used in the experiments, but only traces of succinate and propionate were found in starving animals, whereas acetate was present in the water in proportions of $8-18 \%$ of the lactate accumulated. It is uncertain whether acetate was indeed an end-product of the isopod's own metabolism. The appearance of substantial quantities of succinate in animals after feeding would suggest that these metabolites originated largely from the activity of micro-organisms.

In conclusion, hitherto all observations have shown that in hypoxia or anoxia Crustacea rely on glycolysis and accumulate lactate as main end-product whereas other metabolites are quantitatively insignificant. Considering the wide distribution of succinate fermentation and formation of volatile fatty acids amongst invertebrate animals, it is surprising that, as far as we know, crustaceans generally do not use this particular mode of anaerobic energy production. Perhaps there was no necessity for crustaceans to become adapted to long-term environmental anaerobiosis because, as a rule, they are very mobile and, therefore, could easily escape such conditions.

Obviously, Upogebia pugettensis and Callianassa californiensis were able to conquer such extreme places as the mud flats in the intertidal zone where often completely anoxic layers exist only a few centimeters from the surface of the sediments. As was shown above, animals dug out at low tide after more than $7 \mathrm{hr}$ of emersion had significantly lower concentrations of lactate than individuals exposed to $6 \mathrm{hr}$ of experimental anoxia. This observation suggests that. under natural conditions, these thalassinid shrimps very probably are only hypoxic instead of anoxic even after maximum duration of the low tide; in other words, after the emersion of their habitat they still must have some supply of oxygen. Probably this is the result of the animals' own activity: they ventilate their burrows very efficiently and, in this way, they implement the uptake of oxygen at the air/water interface. Incidentally, ventilation of the water in the burrows of Upogebia can also be observed directly under favourable conditions: the water level in the entrance moves up and down every few seconds.

\section{SUMMARY}

The concentrations of various metabolites in the burrowing intertidal Thalassinidea Upogebia pugettensis and Callianassa californiensis were measured after different periods of anoxia and under the conditions of the natural habitat.

Glycogen was found to be the only significant substrate of anaerobic metabolism and lactate was the main end-product accumulating in large quantities. In addition, the level of aspartate decreased during anaerobiosis and succinate concentration rose. L-Alanine also was a minor end-product.

Striking differences between both species were 
shown in the stores of glycogen and in the rates of its anaerobic degradation as well as in the extent of lactate accumulation, Upogebia exceeding Callianassa considerably. Quantitatively, the utilization of substrate corresponded well with the end-product formed. The resistance of anoxia is much higher in Callianassa than in Upogebia. In the natural habitat the level of lactate was found to rise during emersion at low tide, however, the accumulation was small compared to that measured after $6 \mathrm{hr}$ of experimental anoxia.

The results are discussed in relation to their comparative aspects.

Acknowledgements-The author wishes to thank Dr Eugene N. Kozloff and the staff of the Friday Harbor Laboratories for their help and cooperation.

\section{REFERENCES}

Barnes H., Finlayson D. M. \& Piatogorsky J. (1963) The effect of desiccation and anaerobic conditions on the behaviour, survival and general metabolism of three common cirripeds. J. Anim. Ecol. 32m, 233-252.

BergMEYER H. U. (Ed.) (1974) Methoden der enzymatischen Analyse, Vol. II, 3rd edn. Verlag Chemie, Weinheim.

BRAND T. VON (1946) Anaerobiosis in Invertebrates, Biodynamica Monographs No. 4, Normandy, Missouri.

Collicutt J. \& HochachKa P. W. (1977) The anaerobic oyster heart: coupling of glucose and aspartate fermentation. J. comp. Physiol. 115, 147-157.

FELBECK H. (1980) Investigations on the role of the amino acids in anaerobic metabolism in the lug-worm Arenicola marina. J. comp. Physiol. 137, 183-192.

Hill B. (1981) Respiratory adaptations of three species of
Upogebia (Thalassinidea, Crustacea) with special reference to low tide periods. Biol. Bull. 160, 272-279.

MACGINITIE G. E. (1930) The natural history of the mud shrimp Upogebia pugettensis. Ann. Mag. Nat. Hist. 6, 36-44.

MACGinitie G. E. (1934) The natural history of Callianassa californiensis. Am. Midl. Naturalist 15, 166-177.

PritchaRd A. W. \& EDDY S. (1979) Lactate formation in Callianassa californiensis and Upogebia pugettensis. Mar. Biol. 50, 249-253.

SCHÖTtLER U. (1980) Der Energiestoffwechsel bei biotopbedingter Anaerobiose: Untersuchungen an Anneliden. Verh. Dtsch. Zool. Ges. 228-240.

SCHÖtTLER U. \& SCHRofF G. (1976) Untersuchungen zum anaeroben Glykogenabbau bei Tubifex tubifex. J. comp. Physiol. 108, 243-254.

Surholt B. (1977) Production of volatile fatty acids in the anaerobic carbohydrate catabolism of Arenicola marina. Comp. Biochem. Physiol. 58B, 147-150.

TEAL J. A. \& Carey F. G. (1967) The metabolism of marsh crabs under conditions of reduced oxygen pressure. $P h y$ siol. Zool. 40, 83-91.

Thompson R. K. \& Pritchard A. W. (1969) Respiratory adaptations of the two burrowing crustaceans Callianassa californiensis and Upogebia pugettensis. Biol. Bull. 136, $274-287$.

WILPS H. \& ZEBE E. (1976) The end-products of anaerobic carbohydrate metabolism in the larvae of Chironomus thummi thummi. J. comp. Physiol. 112, 263-272.

ZeBE E. (1975) In vivo-Untersuchungen über den GlukoseAbbau bei Arenicola marina (Annelida, Polychaeta). $J$. comp. Physiol. 101, 133-147.

ZWAAN A. DE (1977) Anaerobic energy metabolism in bivalve molluses Oceanogr. Mar. Biol. Ann. Rev. 15, 103-187.

ZWaAn A. DE \& SKJoldal. H. R. (1979) Anaerobic energy metabolism of the scavenging isopod Cirrolana borealis. J. comp. Physiol. 129, 327-331. 